\title{
Role of serum-derived hyaluronan-associated protein-hyaluronan complex in ovarian cancer
}

\author{
YUKIHIKO OBAYASHI $^{1}$, HIROMITSU YABUSHITA ${ }^{1}$, KOUHEI KANYAMA ${ }^{1}$, MARI NOGUCHI ${ }^{1}$, \\ LISHENG ZHUO $^{2}$, KOJI KIMATA ${ }^{2}$ and AKIHIKO WAKATSUKI ${ }^{1}$ \\ ${ }^{1}$ Department of Obstetrics and Gynecology, ${ }^{2}$ Institute for Molecular Science of Medicine, \\ Aichi Medical University, School of Medicine, Nagakute-cho, Aichi 480-1195, Japan
}

Received November 16, 2007; Accepted January 29, 2008

\begin{abstract}
The objective of this study was to determine if the level of serum hyaluronan (HA), serum-derived HA-associated protein (SHAP)-HA complex, and urinary trypsin inhibitor (UTI) correlate with the clinical outcome of ovarian cancer patients. The relationship of metalloproteinase and its inhibitor with HA and the SHAP-HA complex was also examined. Serum and urine samples were obtained from 45 patients with ovarian cancer, 22 patients with benign ovarian tumors and 50 healthy women. Concentrations of serum HA and UTI were measured by an inhibitory sandwich enzyme-linked immunosorbent assay, and concentrations of the serum SHAP-HA complex were measured by a sandwich enzymelinked immunosorbent assay. Concentrations of MMP-2, MMP-9 and TIMP-1 were measured by a one-step enzyme immunoassay. The levels of HA, SHAP-HA complex, MMP-9 and TIMP-1 were higher in the ovarian cancer group than in the benign ovarian tumor group. In ovarian cancer patients, the levels of HA, SHAP-HA complex and MMP-9 were higher in the stage III/IV group than in the stage I/II group, and the levels of SHAP-HA complex, MMP-9 and TIMP-1 were higher in the non-responder group than in the responder group. The serum concentration of SHAP-HA complex had a significant correlation with HA, MMP-9 and TIMP-1 in ovarian cancer patients. The patients with elevated SHAP-HA complex had a shorter disease-free survival compared with those with normal levels of SHAP-HA complex. The multiple regression analysis revealed that SHAP-HA complex is the significant independent variable for progression-free survival. The elevated level of SHAP-HA complex may indicate the prognosis of recurrence and reflect the tumor metastasis associated with MMP-9 in ovarian cancer patients.
\end{abstract}

Correspondence to: Dr Hiromitsu Yabushita, Department of Obstetrics and Gynecology, Aichi Medical University, School of Medicine, 21 Karimata, Yazako, Nagakute-cho, Aichi-gun, Aichi 480-1195, Japan

E-mail: yab@aichi-med-u.ac.jp

Key words: ovarian cancer, metastasis, hyaluronan, SHAP-HA complex, metalloproteinase

\section{Introduction}

Epithelial ovarian cancer is the prime cause of cancer death among women with gynecological malignancies. Late stage at diagnosis is responsible for the high mortality rate for this cancer, as more than $70 \%$ of patients are diagnosed at an advanced stage. The main route of metastatic dissemination of epithelial ovarian cancer is by exfoliation of the tumor cells, which migrate, implant and invade throughout the peritoneal cavity. The molecular mechanisms underlying this process are not well characterized; but, it is likely that the interaction between the ovarian cancer cells and peritoneal mesothelium is mediated by specific adhesion molecules (1).

Hyaluronan (HA) is an extracellular polysaccharide typically present in the extracellular matrix of some epithelial and neural tissues. HA is particularly abundant in connective tissues. HA controls cell migration, differentiation and proliferation (2), thereby influencing tissue morphogenesis, wound healing and tumor growth $(3,4)$. HA levels correlate with the invasiveness and metastatic capacity of tumor cells $(5,6)$. Increased HA concentrations may help invasion by providing a less dense matrix for cancer cells (7), stimulating cancer cell motility, and forming an immunoprotective coat for cancer cells (8).

Associations with various HA-binding proteins (HABPs), including proteoglycans, result in tremendously diverse physiological functions for HA. Extracellular matrix containing HA as a major component, called HA-rich matrix, plays important roles in regulating cellular behavior in a variety of physiological and pathological processes via cell-surface HA receptors, such as CD44 and receptor for hyaluronan-mediated motility (RHAMM) (9-12).

Serum-derived HA-associated proteins (SHAPs) correspond to the heavy chains of plasma inter- $\alpha$-trypsin inhibitor (ITI) family molecules and are bound to HA via a unique ester bond (13-15). ITI family molecules are synthesized by hepatocytes and secreted into the blood at high concentrations (16). The heavy chains of these molecules are derived from 3 different genes, and either 1 or 2 of the chains are covalently bound to the light chain, bikunin, to form ITI family members such as ITI, pre- $\alpha$-trypsin inhibitor, and inter- $\alpha$ trypsin-like inhibitor (17). During the formation of SHAP-HA 


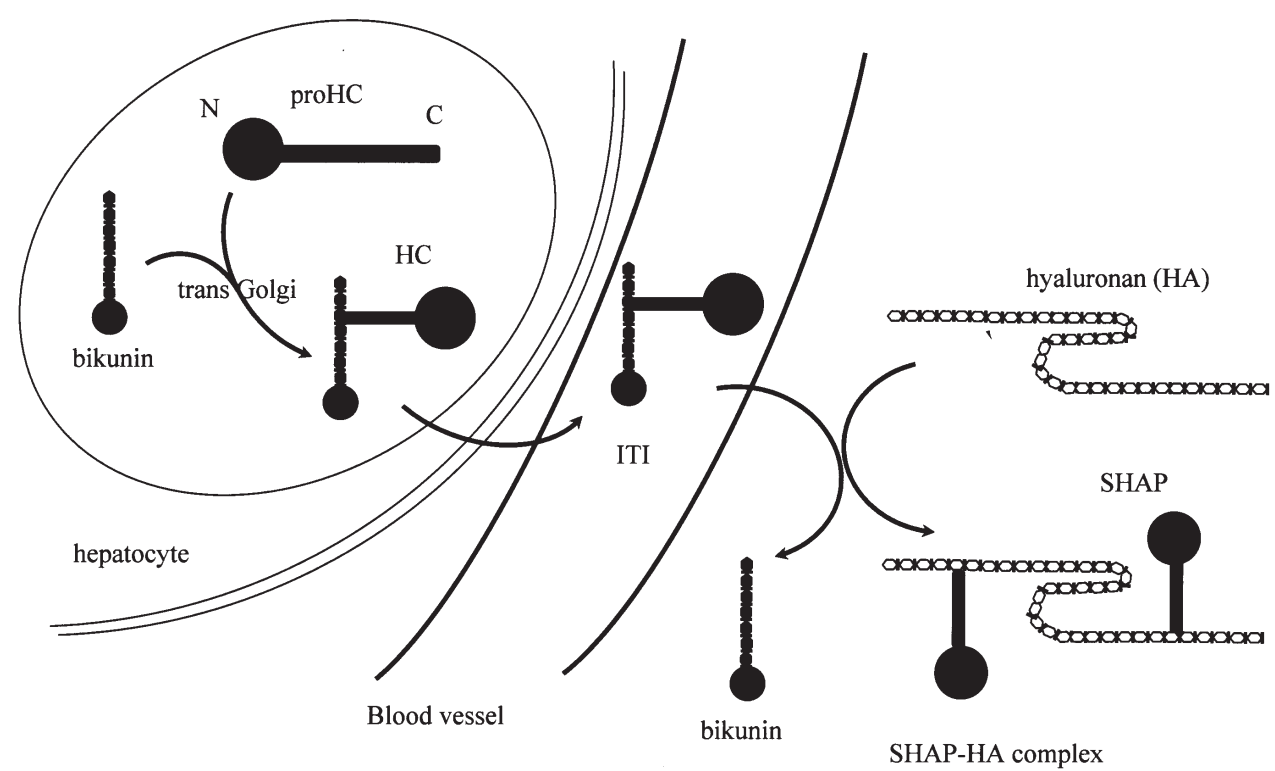

Figure 1. Schematic representation of the synthesis of the SHAP-HA complex. The biosynthesis of inter- $\alpha$-trypsin inhibitor (ITI) occurs in hepatocytes. The heavy chains (HC) are first synthesized in their precursor forms. Then, in the trans Golgi, they are coupled to the chondroitin sulfate chain of bikunin, accompanied by the removal of the C-terminal extensions. The HC-bikunin complexes are circulating in the blood at high concentrations. When necessary, they are recruited to local sites and the heavy chain moieties were transferred to hyaluronan (HA) to form the SHAP-HA complex. The released bikunin is rapidly excreted into the urine, where it is also widely known as the urinary trypsin inhibitor.

complexes, HA is substituted for the chondroitin sulfate chain of bikunin, accompanied by the release of bikunin (Fig. 1) (14,18). Released bikunin is excreted in urine as urinary trypsin inhibitor (UTI). The SHAP-HA complex was originally discovered in HA-rich matrix from cultured mouse dermal fibroblasts, and SHAP was found to be derived from serum supplemented to culture media $(13,15)$.

Matrix metalloproteases (MMPs) play a crucial role in tissue remodeling in a variety of physiological and pathological processes, similar to the roles of HA. In ovarian cancer, high levels of HA and MMP-9 in tumor stroma predict poor survival, and HA may possibly influence the expression of MMP-9 as well as the conversion of the inactive pro-forms to active forms $(19,20)$.

The goal of the present study was to determine if the levels of serum HA, the SHAP-HA complex and UTI correlate with the clinical outcome of ovarian cancer patients. The relationship of metalloproteinase and its inhibitor, tissue inhibitor of metalloproteinases 1 (TIMP1), with HA and the SHAP-HA complex was also examined.

\section{Materials and methods}

Serum and urine were obtained from 45 patients with ovarian cancer, 22 patients with benign ovarian tumors and 50 healthy women. All patients attended the gynecology clinic at Aichi Medical University Hospital from June 1995 to December 2004. A laparotomy and pathological diagnosis were performed in all cases of ovarian cancer and benign ovarian tumors. The study was approved by the regional ethics committee of Aichi Medical University School of Medicine. Written informed consent was obtained from all participants prior to study enrollment. Of the 45 ovarian cancer patients, 19 had stage I disease, 6 had stage II disease, 16 had stage III disease, and 4 had stage IV disease. Nineteen patients had serous adenocarcinoma, 1 had mucinous adenocarcinoma, 6 had endometrioid adenocarcinoma, 16 had clear cell adenocarcinoma, 1 had carcinosarcoma, 1 had squamous cell carcinoma and 1 had undifferentiated adenocarcinoma (Table I). After laparotomy, 25 patients received 4 cycles of adjuvant chemotherapy with paclitaxel and carboplatin, and 20 patients who had residual tumors received 6 cycles of remission-induction chemotherapy using carboplatin and paclitaxel or irinotecan. The observed progression-free survival time was longer than 24 months.

Concentrations of HA were measured using an inhibitory enzyme-linked immunosorbent assay (ELISA) (21). HAbovine serum albumin (BSA) plates (Seikagaku Corp., Tokyo, Japan) were washed 3 times with phosphate-buffered saline (PBS) containing $0.1 \%$ Tween-20 (PBS-T). Then, $50 \mu 1$ each of sample (diluted 1:5-10 with PBS-T), and 50 $\mu \mathrm{l}$ each of biotinylated HABP $(0.5 \mu \mathrm{g} / \mathrm{ml}$ in $1 \% \mathrm{BSA} / \mathrm{PBS}-\mathrm{T})$ was applied to each well, and plates were incubated at $37^{\circ} \mathrm{C}$ for $1 \mathrm{~h}$. After washing with PBS-T, $50 \mu 1$ of horseradish peroxidase-streptavidin (1:500) was added to each well, and plates were further incubated at $37^{\circ} \mathrm{C}$ for $1 \mathrm{~h}$. Color development was achieved by incubating with $50 \mu 1$ of tetramethylbenzidine (TMB) solution at $37^{\circ} \mathrm{C}$ for $10 \mathrm{~min}$; then, the reaction was stopped using $50 \mu 1$ of $1 \mathrm{M} \mathrm{HCl}$. Absorbance at $450 / 630 \mathrm{~nm}$ was measured with an immuno Mini NI-2300 spectrophotometer. Assays were performed in triplicate.

Concentrations of SHAP-HA complex in serum were determined by measuring the amount of SHAPs using a sandwich ELISA (21). Microtiter plates were coated with $\operatorname{HABP}(4 \mu \mathrm{g} / \mathrm{ml}$ in $0.1 \mathrm{M}$ sodium carbonate buffer; $\mathrm{pH} 9.5)$ at $4^{\circ} \mathrm{C}$ for $15 \mathrm{~h}$. Wells were washed twice with $200 \mu \mathrm{l}$ of PBS, followed by blocking with $200 \mu 1$ of $3 \%$ BSA in PBS-T at room temperature for $1 \mathrm{~h}$. After washing the wells 3 times 
Table I. Characteristics of 45 patients with ovarian cancer.

\begin{tabular}{|c|c|}
\hline Age & $\begin{array}{c}57.9 \pm 11.7 \\
(31-84)\end{array}$ \\
\hline \multicolumn{2}{|l|}{ Stage } \\
\hline Ia & 1 \\
\hline $\mathrm{Ib}$ & 7 \\
\hline Ic & 11 \\
\hline IIa & 1 \\
\hline $\mathrm{IIb}$ & 1 \\
\hline IIc & 4 \\
\hline IIIa & 2 \\
\hline IIIb & 1 \\
\hline IIIc & 13 \\
\hline IV & 4 \\
\hline \multicolumn{2}{|l|}{ Histology } \\
\hline Serous & 19 \\
\hline Mucinous & 1 \\
\hline Endometrioid & 6 \\
\hline Clear cell & 16 \\
\hline Others & 3 \\
\hline \multicolumn{2}{|l|}{ Response } \\
\hline $\mathrm{CR}$ & 8 \\
\hline PR & 6 \\
\hline $\mathrm{NC}$ & 1 \\
\hline PD & 5 \\
\hline
\end{tabular}

$\mathrm{CR}$, complete response; PR, partial response; NC, no change; PD, progressive disease.

with $200 \mu \mathrm{l}$ of PBS-T, $50 \mu 1$ each of sample (serum diluted 1:5-10 with PBS) in 1\% BSA/PBS-T was added to each well. Then, plates were incubated at $37^{\circ} \mathrm{C}$ for $1 \mathrm{~h}$. After washing, $25 \mu 1$ of rabbit anti-human ITI antibody (diluted 1:3000 with $1 \%$ BSA/PBS-T) and $25 \mu 1$ of HRP-conjugated goat antirabbit immunoglobulins antibody (diluted 1:3000 with $1 \%$ BSA/PBS-T) was added to each well and incubated at $37^{\circ} \mathrm{C}$ for $1 \mathrm{~h}$. Wells were washed 3 times, then they were incubated with $50 \mu \mathrm{l}$ each of $\mathrm{TMB}$ solution at $37^{\circ} \mathrm{C}$ for $10 \mathrm{~min}$. The reaction was stopped by the addition of $50 \mu 1$ of $1 \mathrm{M} \mathrm{HCl}$, and absorbance at $450 / 650 \mathrm{~nm}$ was measured. Assays were performed in triplicate.

Concentrations of UTI were measured using an inhibitory ELISA. Microtiter plates were coated with UTI $(2 \mu \mathrm{g} / \mathrm{ml}$ in $0.1 \mathrm{M}$ sodium carbonate buffer; $\mathrm{pH} 9.5)$ at $4^{\circ} \mathrm{C}$ overnight and then blocked with $3 \%$ BSA as above. The plates were washed 3 times with PBS-T, then $50 \mu 1$ of sample (urine diluted 1:510 with PBS) and $50 \mu 1$ of anti-UTI antibodies were applied to each well and incubated at $37^{\circ} \mathrm{C}$ for $1 \mathrm{~h}$. Wells were washed, and $100 \mu 1$ of HRP-conjugated goat anti-rabbit antibody was added to each well. Plates were then further incubated at $37^{\circ} \mathrm{C}$ for $1 \mathrm{~h}$. After washing with PBS-T, color development was achieved by incubation with $50 \mu 1$ of TMB solution at $37^{\circ} \mathrm{C}$ for $10 \mathrm{~min}$, then the reaction was stopped using $50 \mu \mathrm{l}$ of $1 \mathrm{M} \mathrm{HCl}$. Absorbance at 450/650 nm was measured. Assays were performed in triplicate.

Concentrations of serum MMP-2, MMP-9 and TIPM-1 were measured with a one-step sandwich EIS system by using monoclonal antibodies against human MMP-2, MMP-9 and TIMP-1 (Fuji Chemical Co., Toyama, Japan) as reported previously (22-24). A specimen $(10 \mu \mathrm{l})$ was mixed with $100 \mu 1$ of $50 \mu \mathrm{g} / \mathrm{l}$ each antibody conjugated with HRP in $10 \mathrm{mM}$ sodium phosphate buffer ( $\mathrm{pH} 7.0$ ) containing $10 \mathrm{~g} / 1 \mathrm{BSA}$, $10 \mathrm{nM}$ EDTA and $0.1 \mathrm{M} \mathrm{NaCl}$. A $100 \mu \mathrm{l}$ aliquot of the mixture was transferred to each microplate well previously coated with each antibody. The plate was incubated for $60 \mathrm{~min}$ at room temperature and then washed 3 times with PBS. Color development was achieved by incubation with $100 \mu 1$ of citric acid-sodium phosphate buffer containing phenylenediamine and hydrogen peroxide at room temperature for $20 \mathrm{~min}$. The reaction was stopped with $100 \mu \mathrm{l}$ of $1 \mathrm{M} \mathrm{HCl}$, and the absorbance at $492 \mathrm{~nm}$ was measured. Assays were performed in triplicate.

The upper limits of normal levels were defined as the mean value plus 2 times the standard deviation of the values from the control group (50 healthy women). These upper limits of normal values were: $100 \mathrm{ng} / \mathrm{ml}$ for $\mathrm{HA}, 5 \mathrm{U} / \mathrm{ml}$ for SHAP-HA complex, $5 \mu \mathrm{g} / \mathrm{ml}$ for UTI, $1000 \mathrm{ng} / \mathrm{ml}$ for MMP-2, $500 \mathrm{ng} / \mathrm{ml}$ for MMP-9 and $200 \mathrm{ng} / \mathrm{ml}$ for TIMP-1.

Differences between categories were analyzed with the Student's t-test. Correlation was analyzed by using Pearson's correlation coefficient, and multivariate analysis was performed by using the multiple regression method. Progressionfree survival was analyzed by the Kaplan-Meier method and log-rank test. P-values $<0.05$ were considered statistically significant.

\section{Results}

The levels of HA, SHAP-HA complex, MMP-9 and TIMP-1 were higher in the ovarian cancer group than in the benign ovarian tumor group (Table II). Among the 45 ovarian cancer patients, the levels of HA, SHAP-HA complex and MMP-9 were higher in the stage III/IV group than in the stage I/II group (Table III). However, no differences in the levels of HA, SHAP-HA complex, UTI, MMP-2, MMP-9 or TIMP-1 were found among the histological types (Table IV). In the 20 ovarian cancer patients treated with remission-inducing chemotherapy after tumor-reduction surgery, the levels of SHAP-HA complex, MMP-9 and TIMP-1 were higher in the non-responder group than in the responder group (Table V). The serum concentration of the SHAP-HA complex was significantly correlated with the levels of MMP-9, and TIMP-1 in the 45 ovarian cancer patients (Fig. 2). The patients with elevated levels of the SHAP-HA complex had a shorter disease-free survival compared with patients with normal levels of the SHAP-HA complex (Fig. 3). For HA, UTI, MMP-9 and TIMP-1, the positive group had also a shorter diseasefree survival compared with the negative group, whereas no difference was found for MMP-2. Multiple regression analysis revealed that the level of the SHAP-HA complex is a significant independent variable that predicts a shorter progressionfree survival (Table VI). 
Table II. Serum HA, SHAP-HA complex, MMP-2, MMP-9, TIMP-1 and UTI in ovarian cancer patients and benign ovarian tumor patients.

\begin{tabular}{lccccccc}
\hline $\begin{array}{l}\text { Diagnosis } \\
\text { No. }\end{array}$ & $\begin{array}{c}\mathrm{HA} \\
(\mathrm{ng} / \mathrm{ml})\end{array}$ & $\begin{array}{c}\text { SHAP-HA } \\
(\mathrm{U} / \mathrm{ml})\end{array}$ & $\begin{array}{c}\text { UTI } \\
(\mu \mathrm{g} / \mathrm{ml})\end{array}$ & $\begin{array}{c}\text { MMP-2 } \\
(\mathrm{ng} / \mathrm{ml})\end{array}$ & $\begin{array}{c}\text { MMP-9 } \\
(\mathrm{ng} / \mathrm{ml})\end{array}$ & $\begin{array}{c}\text { TIMP-1 } \\
(\mathrm{ng} / \mathrm{ml})\end{array}$ \\
\hline Ovarian cancer & 45 & $488.8 \pm 902.0$ & $7.01 \pm 10.93$ & $7.70 \pm 11.37$ & $769.7 \pm 302.0$ & $632.6 \pm 355.5$ & $262.5 \pm 113.4$ \\
$\begin{array}{l}\text { Benign ovarian } \\
\text { tumor }\end{array}$ & 22 & $44.6 \pm 28.6$ & $2.19 \pm 2.29$ & $3.65 \pm 5.77$ & $818.1 \pm 164.4$ & $419.1 \pm 248.3$ & $156.6 \pm 25.0$ \\
\begin{tabular}{l} 
P-value \\
\hline
\end{tabular} & & 0.0246 & 0.0456 & $\mathrm{~ns}$ & $\mathrm{~ns}$ & 0.0140 & $<0.0001$ \\
\hline
\end{tabular}

ns, non-significant.

Table III. Serum HA, SHAP-HA complex, MMP-2, MMP-9, TIMP-1 and UTI in stages I/II and III/IV ovarian cancer patients.

\begin{tabular}{lccccccc}
\hline Stage & No. & $\begin{array}{c}\text { HA } \\
(\mathrm{ng} / \mathrm{ml})\end{array}$ & $\begin{array}{c}\text { SHAP-HA } \\
(\mathrm{U} / \mathrm{ml})\end{array}$ & $\begin{array}{c}\text { UTI } \\
(\mu \mathrm{g} / \mathrm{ml})\end{array}$ & $\begin{array}{c}\text { MMP-2 } \\
(\mathrm{ng} / \mathrm{ml})\end{array}$ & $\begin{array}{c}\text { MMP-9 } \\
(\mathrm{ng} / \mathrm{ml})\end{array}$ & $\begin{array}{c}\text { TIMP-1 } \\
(\mathrm{ng} / \mathrm{ml})\end{array}$ \\
\hline I/II & 25 & $218.8 \pm 251.9$ & $4.10 \pm 4.51$ & $4.81 \pm 5.83$ & $792.9 \pm 343.3$ & $487.9 \pm 330.9$ & $249.4 \pm 131.6$ \\
III/IV & 20 & $826.4 \pm 1260.2$ & $10.63 \pm 15.02$ & $11.30 \pm 15.22$ & $740.6 \pm 246.4$ & $813.4 \pm 303.9$ & $278.9 \pm 86.2$ \\
P-value & & 0.0229 & 0.045 & $\mathrm{~ns}$ & $\mathrm{~ns}$ & 0.0015 & $\mathrm{~ns}$ \\
\hline
\end{tabular}

ns, non-significant.

Table IV. Serum HA, SHAP-HA complex, MMP-2, MMP-9, TIMP-1 and UTI in different histological types of ovarian cancer.

\begin{tabular}{lccccccc}
\hline Histology & No. & $\begin{array}{c}\text { HA } \\
(\mathrm{ng} / \mathrm{ml})\end{array}$ & $\begin{array}{c}\text { SHAP-HA } \\
(\mathrm{U} / \mathrm{ml})\end{array}$ & $\begin{array}{c}\text { UTI } \\
(\mu \mathrm{g} / \mathrm{ml})\end{array}$ & $\begin{array}{c}\text { MMP-2 } \\
(\mathrm{ng} / \mathrm{ml})\end{array}$ & $\begin{array}{c}\text { MMP-9 } \\
(\mathrm{ng} / \mathrm{ml})\end{array}$ & $\begin{array}{c}\text { TIMP-1 } \\
(\mathrm{ng} / \mathrm{ml})\end{array}$ \\
\hline Serous & 19 & $357.9 \pm 387.9$ & $4.85 \pm 7.28$ & $6.92 \pm 10.02$ & $768.3 \pm 292.8$ & $598.3 \pm 288.1$ & $261.5 \pm 111.8$ \\
Mucinous & 1 & 106.7 & 1.26 & 2.3 & 356 & 390 & 198 \\
Endometrioid & 6 & $806.3 \pm 1065.5$ & $11.74 \pm 23.22$ & $3.90 \pm 1.20$ & $732.5 \pm 279.6$ & $613.3 \pm 352.9$ & $262.7 \pm 96.3$ \\
Clear cell & 16 & $265.8 \pm 289.1$ & $7.02 \pm 6.38$ & $2.88 \pm 10.32$ & $808.5 \pm 314.9$ & $663.6 \pm 449.9$ & $269.9 \pm 138.4$ \\
Others & 3 & $2000.2 \pm 2952.9$ & $12.99 \pm 17.73$ & $23.10 \pm 26.76$ & $783.7 \pm 440.1$ & $803.3 \pm 331.7$ & $250.3 \pm 31.9$ \\
\hline
\end{tabular}

Table V. Serum HA, SHAP-HA complex, MMP-2, MMP-9, TIMP-1 and UTI in the responder group and non-responder group in ovarian cancer patients.

\begin{tabular}{lccccccc}
\hline Response & No. & $\begin{array}{c}\text { HA } \\
(\mathrm{ng} / \mathrm{ml})\end{array}$ & $\begin{array}{c}\text { SHAP-HA } \\
(\mathrm{U} / \mathrm{ml})\end{array}$ & $\begin{array}{c}\text { UTI } \\
(\mu \mathrm{g} / \mathrm{ml})\end{array}$ & $\begin{array}{c}\text { MMP-2 } \\
(\mathrm{ng} / \mathrm{ml})\end{array}$ & $\begin{array}{c}\text { MMP-9 } \\
(\mathrm{ng} / \mathrm{ml})\end{array}$ & $\begin{array}{c}\text { TIMP-1 } \\
(\mathrm{ng} / \mathrm{ml})\end{array}$ \\
\hline CR/PR & 14 & $700.6 \pm 1387.2$ & $5.78 \pm 8.45$ & $11.42 \pm 15.64$ & $765.6 \pm 270.6$ & $703.4 \pm 265.3$ & $251.4 \pm 63.3$ \\
NC/PD & 6 & $1119.8 \pm 940.6$ & $21.96 \pm 21.24$ & $11.03 \pm 15.62$ & $682.2 \pm 185.7$ & $1070.0 \pm 234.7$ & $343.0 \pm 103.6$ \\
P-value & & $\mathrm{ns}$ & 0.0227 & $\mathrm{~ns}$ & $\mathrm{~ns}$ & 0.0091 & 0.0248 \\
\hline
\end{tabular}

aThese patients were treated with chemotherapy after reduction surgery. CR, complete response; PR, partial response; NC, no change; PD, progressive disease; ns, non-significant. 

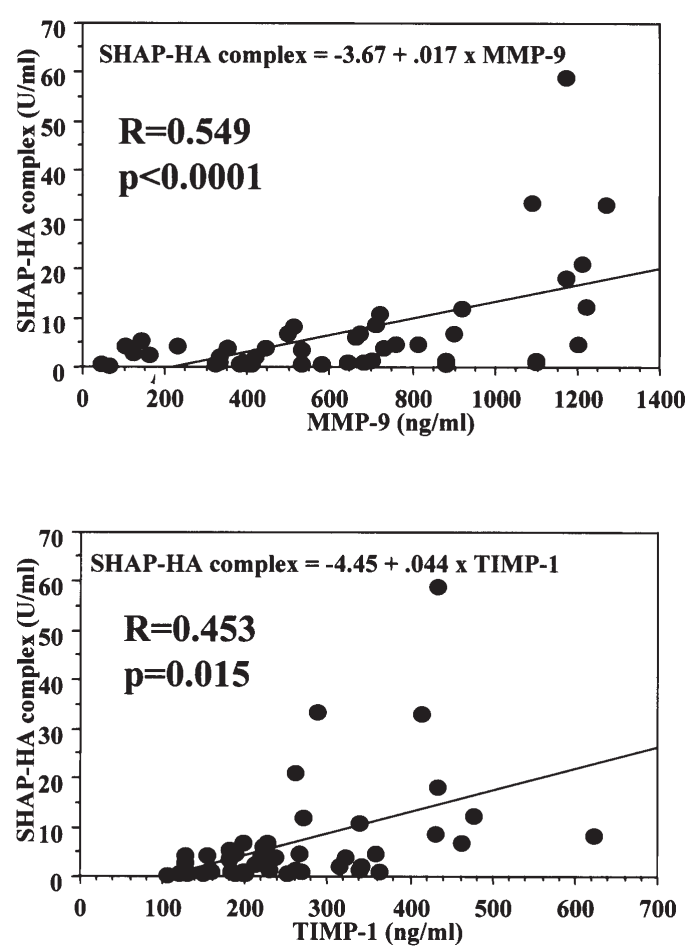

Figure 2. Correlations of serum SHAP-HA complex with MMP-9 and TIMP-1 in patients with ovarian cancer.

\section{Discussion}

The multistage process of tumor invasion and metastasis depends on several mechanisms, including stimulation of cell growth by growth factors, destruction of the extracellular matrix by proteolytic enzymes (25), neovascularization due to the presence of angiogenic factors $(26,27)$, and cell-to-cell or stromal adhesion regulated by cell adhesion molecules.

Significantly increased levels of HA are often associated with certain types of human tumors, and the levels of HA in
Table VI. Multiple regression analysis for progression-free survival in ovarian cancer patients.

\begin{tabular}{lrrrr}
\hline Variables & $\begin{array}{c}\text { Regression } \\
\text { coefficient }\end{array}$ & $\begin{array}{c}\text { Standard } \\
\text { error }\end{array}$ & T-value & P-value \\
\hline Intercept & 79.34 & 13.02 & 6.093 & $<0.0001$ \\
Age & -0.251 & 0.19 & -1.895 & 0.066 \\
Stage & -0.15 & 2.19 & -1.109 & 0.274 \\
HA & 0.114 & 0 & 0.667 & 0.508 \\
SHAP-HA & -0.384 & 0.29 & -2.094 & 0.043 \\
complex & & & & \\
UTI & -0.173 & 0.2 & -1.305 & 0.2 \\
MMP-2 & -0.248 & 0 & -1.79 & 0.081 \\
MMP-9 & -0.188 & 0 & -1.117 & 0.271 \\
TIMP-1 & 0.016 & 0.02 & 0.098 & 0.922 \\
\hline
\end{tabular}

the serum of some cancer patients are significantly greater than those of normal individuals $(7,28-30)$. Although increased HA synthesis is not a universal characteristic of tumors, there seems to be an overall tendency for transformed cells to exhibit higher levels of HA production (31-33). In addition, a close relationship has been demonstrated between HA production and malignant phenotype, such as invasiveness (34). Our and another group found that highly metastatic cell lines release more HA into culture medium than less metastatic variants $(5,6)$. Furthermore, Zhang et al (4) reported that HA on the surface of tumor cells is correlated with metastatic behavior.

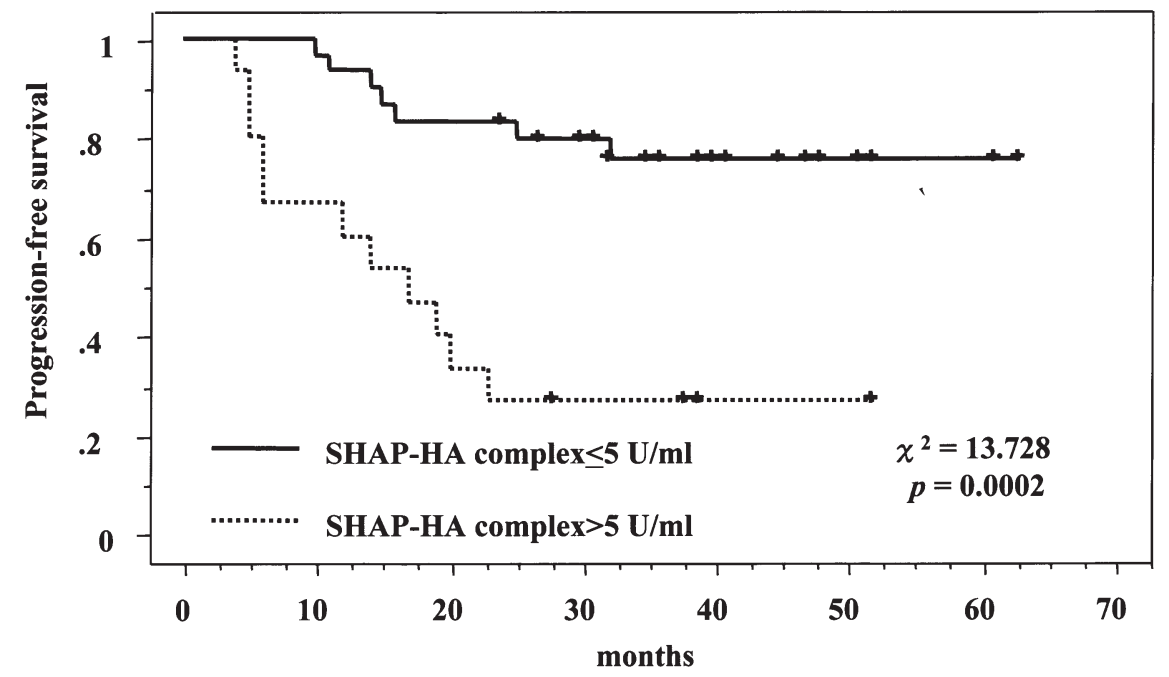

Figure 3. Progression-free survival in ovarian cancer patients was compared between 15 cases with positive SHAP-HA complex levels and 30 cases with negative SHAP-HA complex levels. 
HA has either directly or indirectly been implicated in cell adhesion, motility, growth and differentiation (35). HA-binding proteins regulate cellular behavior by interacting with HA and forming the HA pericellular matrix (36). Increased matrix deposition of HA may favor tumor growth and invasion by increasing tissue hydration and providing a suitable environment for cell migration analogous to embryonic cell movement. Additional mechanisms may also help the HA matrix in favoring tumor growth. For example, the HA pericellular coat may reduce the access of immune cells to tumor cells (8). Tumor cells are surrounded by a thick pericellular coat that is sensitive to hyaluronidase. Removal of this coat may allow lymphocytes to exert their cytolytic effect on tumor cells. Additionally, partially degraded HA fragments promote angiogenesis, an important host contribution to tumor cell viability (37).

Our previous study (38) demonstrates that increased expression of HA synthase 1 (HAS1) in tumor cells is a significant prognostic parameter, independent of conventional factors related to tumor spreading at diagnosis and residual tumor size. Furthermore, HAS1 expression correlated with the microvessel density in the tumor, but it was unrelated to CD44 expression. Yamada et al (39) reported that elevated transcription levels of the HAS1 gene correlated with poor prognosis of human colon cancer. Anttila et al (40) reported that elevated levels of stromal HA indicate that the tumor is aggressive and predict poor disease outcome in ovarian cancer patients, especially those with serous tumors. Kayastha et al (41) reported that CD44 expression is associated with the spread of ovarian cancer and is an independent predictor of survival. HA contributes to tumor growth, invasion and metastasis through cell proliferation, movement, adhesion and angiogenesis. It is possible that these functions of HA depend on the overexpression of the HAS genes. The three subtypes of HAS may synthesize HAs with different biological functions. Our data suggest that HA synthesized by HAS 1 is associated with tumor neovascularization and predicts tumor aggressiveness and patient survival in ovarian cancer (38).

In the present study, the levels of serum HA and the SHAP-HA complex were greater in the ovarian cancer group than in the benign ovarian tumor group. This finding shows that the synthesis of HA in ovarian cancer tissue is increased and that this HA reacts with ITI, resulting in increased levels of the SHAP-HA complex. In the ovarian cancer patients, the serum levels of HA and the SHAP-HA complex were greater in the stage III/IV group than in the stage I/II group, indicating that the increased levels of HA and the SHAP-HA complex are related to tumor invasion and metastasis. In the same way, the serum levels of MMP-9 and TIMP-1 were significantly greater in the ovarian cancer group than in the benign ovarian tumor group, and serum MMP-9 was elevated according to tumor progression. Thus, MMP-9 is associated with tumor invasion and metastasis in ovarian cancer. Moreover, the ovarian cancer patients with elevated levels of SHAP-HA complex had a shorter disease-free survival time compared to those patients with normal levels of SHAP-HA complex, and the multiple regression analysis revealed that the SHAP-HA complex is a significant independent variable predicting a shorter progression-free survival. These results suggest that the SHAP-HA complex is a useful marker to predict disease recurrence. Because the levels of the SHAPHA complex showed a significant positive correlation with the levels of MMP-9 and TIMP-1, the SHAP-HA complex may promote the synthesis and activation of MMP-9 and TIMP-1 in ovarian cancer progression.

\section{References}

1. Zetter BR: Adhesion molecules in tumor metastasis. Semin Cancer Biol 4: 219-229, 1993.

2. Toole B: Glycosaminoglycans in morphogenesis. In: Cell Biology of the Extracellular Matrix. Hay E (ed). Plenum Press, New York, pp259-294, 1982.

3. Mast BA, Diegelmann RF, Krummel TM and Cohen IK: Scarless wound healing in the mammalian fetus. Surg Gynecol Obstet 174: 441-451, 1992.

4. Zhang L, Underhill CB and Chen L: Hyaluronan on the surface of tumor cells is correlated with metastatic behavior. Cancer Res 55: 428-433, 1995.

5. Kimata K, Honma Y, Okayama M, Oguri K, Hozumi M and Suzuki S: Increased synthesis of hyaluronic acid by mouse mammary carcinoma cell variants with high metastatic potential. Cancer Res 45: 5098-5105, 1985.

6. Turley EA and Tretiak M: Glycosaminoglycan production by murine melanoma variants in vivo and in vitro. Cancer Res 43: $1347-1354,1983$

7. Knudson W: Tumor-associated hyaluronan. Am J Pathol 148: 1721-1726, 1996.

8. McBride WH and Brad JBL: Hyaluronidase-sensitive halos around adherent cells: their role in blocking lymphocytemediated cytolysis. J Exp Med 149: 507-515, 1979.

9. Toole BP: Hyaluronan and its binding protein, the hyaladherins. Curr Opin Cell Biol 2: 839-844, 1990.

10. Underhill C: CD44: the hyaluronan receptor. J Cell Sci 103: 293-298, 1992.

11. Masselis-Smith A, Belch AR, Mant MJ, Turley EA and Pilarski LM: Hyaluronan-dependent motility of B cells and leukemic plasma cells in blood, but not of bone marrow plasma cells, in multiple myeloma: alternate use of receptor for hyaluronan-mediated motility (RHAMM) and CD44. Blood 5: 1891-1899, 1996.

12. Jackson RL, Busch SJ and Cardin AD: Glycosaminoglycans: molecular properties, protein interactions, and role in physiological processes. Physiol Rev 71: 481-539, 1991.

13. Yoneda M, Suzuki S and Kimata K: Hyaluronic acid associated with the surfaces of cultured fibroblasts is linked to a serumderived 85-kDA protein. J Biol Chem 265: 5247-5257, 1990.

14. Zhao M, Yoneda M, Ohashi Y, Kurono S, Iwata H and Kimata K: Evidence for the covalent binding of SHAP, heavy chains of inter- $\alpha$-trypsin inhibitor, to hyaluronan. J Biol Chem 270: 26657-26663, 1995

15. Huang L, Yoneda M and Kimata K: A serum-derived hyaluronan-associated protein (SHAP) is the heavy chain of the inter- $\alpha$-trypsin Inhibitor. J Biol Chem 268: 26725-26730, 1993.

16. Mizon C, Balduyck M, Albani D, Michalski C, Burnouf T and Mizon J: Development of an enzyme-linked immunosorbent assay for human plasma inter- $\alpha$-trypsin inhibitor (ITI) using specific antibodies against each of the $\mathrm{H}_{1}$ and $\mathrm{H}_{2}$ heavy chains. J Immunol Methods 190: 61-70, 1996.

17. Salier JP: Inter- $\alpha$-trypsin inhibitor: emergence of a family within the Kunitz-type protease inhibitor superfamily. Trends Biochem Sci 15: 435-439, 1990.

18. Zhuo L, Yoneda M, Zhao M, Yingsung W, Yoshida N, Kitagawa Y, Kawamura K, Suzuki T and Kimata K: Defect in SHAP-hyaluronan complex causes severe female infertility. A study by inactivation of the bikunin gene in mice. J Biol Chem 276: 7693-7696, 2001.

19. Isnard N, Legeais JM, Renard G and Robert L: Effect of hyaluronan on MMP expression and activation. Cell Biol Int 25: 735-739, 2001.

20. Sillanpaa S, Anttila M, Voutilainen K, Ropponen K, Turpeenniemi-Hujanen T, Puistola U, Tammi M, Sironen R, Saarikoski S and Kosma VN: Prognostic significance of matrix metalloproteinase-9 (MMP-9) in epithelial ovarian cancer. Gynecol Oncol 104: 296-303, 2007

21. Wannarat Y, Lisheng Z, Matthias M, Yoneda M, Kida D and Kimata K: Molecular heterogeneity of the SHAP-hyaluronan complex. J Biol Chem 278: 32710-32718, 2003. 
22. Fujimoto M, Mouri N, Iwata K, Ohuchi E, Okada Y and Hayakawa T: A one-step sandwich enzyme immunoassay for human matrix metalloproteinase 2 (72-kDa gelatinase/type IV collagenase) using monoclonal antibodies. Clin Chim Acta 221: 91-103, 1993

23. Fujimoto M, Hosokawa N, Iwata K, Shinya T, Okada Y and Hayakawa T: A one-step sandwich enzyme immunoassay for inactive precursor and complexed forms of human matrix metalloproteinase 9 (92-kDa gelatinase/type IV collagenase) using monoclonal antibodies. Clin Chim Acta 231: 79-88, 1994.

24. Kodama S, Iwata K, Iwata H, Yamashita K and Hayakawa T: Rapid one-step sandwich enzyme immunoassay for tissue inhibitor of metalloproteinases. An application for rheumatoid arthritis serum and plasma. J Immunol Methods 127: 103-108, 1990.

25. Narumiya H, Yabushita H, Hirata M, Matsushita S, Noguchi M and Nakanishi M: Increased levels of serum matrix metalloproteinase-9 and its regulators as tumor stage markers in ovarian cancer patients. J Aichi Med Univ Assoc 27: 255-260, 1999.

26. Yabushita H, Noguchi M, Obayashi Y, Kishida T, Noguchi Y, Sawaguchi K and Noguchi M: Angiostatin expression in ovarian cancer. Oncol Rep 10: 1225-1230, 2003.

27. Yabushita H, Shimazu M, Noguchi M, Kishida T, Narumiya H, Sawaguchi K and Noguchi M: Vascular endothelial growth factor activating matrix metalloproteinase in ascitic fluid during peritoneal dissemination of ovarian cancer. Oncol Rep 10: 89-95, 2003.

28. Auvinen PK, Parkkinen JJ, Agren U, Johansson RT, Tammi RH, Eskelinen MJ and Kosma V-M. Expression of hyaluronan in benign and malignant breast lesions. Int J Cancer 74: 477-481, 1997.

29. Ropponen K, Tammi M, Parkkinen JJ, Eskelinen M, Tammi R, Lipponen P, Agren U, Alhava E and Kosma V-M: Tumor cellassociated hyaluronan as an unfavorable prognostic factor in colorectal cancer. Cancer Res 58: 342-347, 1998.

30. Dahl IMS and Laurent TCC: Concentration of hyaluronan in serum of untreated cancer patients with special reference to patients with mesothelioma. Cancer 62: 326-330, 1988.
31. Ishimoto N, Temin HM and Strominger JL: Studies of carcinogenesis by avian sarcoma virus. II. Virus-induced increase in hyaluronic acid synthetase in chicken fibroblasts. J Biol Chem 241: 2052-2057, 1996.

32. Bader JP: Temperature-dependent transformation of cells infected with a mutant of Bryan Rous sarcoma virus. J Virol 10: 267-276, 1972

33. Hopwood JJ and Dorfmann A: Glycosaminoglycan synthesis by cultured human skin fibroblasts after transformation with simian virus 40. J Biol Chem 252: 4777-4785, 1977.

34. Toole BP, Biswas C and Gross J: Hyaluronate and invasiveness of the rabbit V2 carcinoma. Proc Natl Acad Sci USA 76: 6299-6303, 1979 .

35. Laurent TC and Fraser JR: Hyaluronan. FASEB J 6: 2397-2404, 1992.

36. Knudson $\mathrm{CB}$ and Knudson $\mathrm{W}$ : Hyaluronan-binding proteins in development, tissue homeostasis and disease. FASEB J 7 : 1233-1241, 1993.

37. West DC, Hampson IN, Arnold F and Kumar S: Angiogenesis induced by degradation products of hyaluronic acid. Science 228: 1324-1326, 1985.

38. Yabushita H, Noguchi M, Kishida T, Fusano K, Noguchi Y, Itano N, Kimata K and Noguchi M: Hyaluronan synthase expression in ovarian cancer. Oncol Rep 12: 739-743, 2004.

39. Yamada $Y$, Itano N, Narimatsu $H$, Kudo T, Morozumi K, Hirohashi S, Ochiai A, Ueda M and Kimata K: Elevated transcript level of hyaluronan synthase 1 gene correlates with poor prognosis of human colon cancer. Clin Exp Metastasis 21: 57-63, 2004.

40. Anttila MA, Tammi RH, Tammi MI, Syrjanen KJ, Saarikoski SV and Kosma VM: High levels of stromal hyaluronan predict poor disease outcome in epithelial ovarian cancer. Cancer Res 60: $150-155,2000$

41. Kayastha S, Freedman AN, Piver MS, Mukkamalla J, RomeroGuittierez M and Werness BA: Expression of the hyaluronan receptor, $\mathrm{CD} 44 \mathrm{~S}$, in epithelial ovarian cancer is an independent predictor of survival. Clin Cancer Res 5: 1073-1076, 1999. 